\title{
EFFECT OF FOLIAR SPRAYING WITH HUMIRON ON GROWTH AND YIELD OF TWO SWEET PEPPERS HYBRID ( CAPSICUMANNUUM L. ) IN OPEN FIELD
}

\author{
Abduljebbar I. SAeid ${ }^{*}$, Suhaila RAfeed F. ${ }^{* *}$, OMeed Mohammad D. ${ }^{* *}$ and SAAD Yousf ASWad ${ }^{* *}$ \\ *Dept. of Horticulture, College of Agricultural Engineering sciences, University of Duhok, \\ Kurdistan Region-Iraq \\ *** Research farm Malta Duhok, Kurdistan Region-Iraq
}

(Received: November 1, 2021; Accepted for Publication: December 8, 2021 )

\begin{abstract}
This investigation was carried out in Malta research farm, Dohuk government, Kurdistan region / Iraq, in summer season 2019 in open filed to study theeffect of Humiron on growth and yield of two peppers Hybrid ( California wonder and Gulpiner). The results show thathybridGulpinerhad asignificant variance in plant high, superior in branches number, California wonder was significant difference in fruit number,fruit weight, yield per $\mathrm{m}^{2}$ and total yield t.ha-1.Humiron provided the highest value in number of branches at highest level of Humiron and vitamin C, fruits number per plant, and totalyield t.ha-1.
\end{abstract}

KEY WORD: Humiron, peppers Hybrid.

\section{INTRODUCTION}

$\mathbf{P}$ epper (Capsicum annuum. L.) is a memberofthe familySolanaceae .It is identified sweet pepper, green pepper or bell pepper( kuharet al. 2017 ). It is a significantplantproduceconsuminggreatnutritious value. It is a samerespectable source of usualcolorsandresistant-oxidant groupingsvital for humanoid health (Howardet al., 2000). Capsicum, are native to South America(Cheng, 2014)It is now cultivated all over the word . Most of the peppers cultivated in temperate and tropical areas. Cultivar selection is a main choice for pepper farmers. With several variant available, knowing the planned market and faces desired by customers is vital. Cultivators selected variations that produce high yields, have resistance to infections, have an identical harvest ripeness, and durability of production. Fruit shape, color size, flavor, and Capsacin rate are all critical appearances (Kaiser and Ernst, 2014).

Humic acid increases the growth and yield of numerous produce including vegetable(Zandonadiel et.2007).HumironFe Liquid Iron is alack corrector, containing iron in the fullof $2 \%$, chelated and centers with Humicacid. So iron is providing in a form that is voluntarily accessible toremainkept up by plant life in anextensivechange of difficult soils (e.g. alkalineand calcareous soils, sandy soils with littlebiologicalsubstancesatisfied, etc.).

The produce is planned to avoid and right iron lackinallagricultureandhorticultureproduces. It can be beneficialboth to thesoil or a foliarspray. The existence of Humicacids in this constructionprocedures a helpful resultonplant growth as well as on confrontation against biotic and abiotic pressures.

Humic acid is one of the greatestvitalmechanisms of bio-fluidcompound. Since of its molecular construction, it delivers several to produce manufacture. It assistancesfailure up clay compressed soils, contributionsin moving micronutrients from the soil to the plant, improvewaterfield, rises seed sproutingcharges, risewater, airand roots diffusionandexcitesgrowth of micro florapopulacein soilMackowiak 2001). Humicmaterialsinspireplantgrowingwiththemixi ngofmainandslightelement, activatorandinhibitor of numerous enzymes, variations in skinpermeability, biomasainvention(Mackowiaketal.,2001).Humic acidon the cropsizeof soilcontainsofmanymechanisms. Besides, certaininvestigatorsdisplayedthatthefoliarsprayof Humicacid improvednutrientacceptance, plantgrowing, produceandsuperiority in aamount of plant typesKarakurt, Unlu and Padem (2009) ( El-Nemr, El- DesukiM..El- Bassiony A.M and 
Fawziet al 2012). atsmallestpartlyover acumulative nutrient acceptance, portion as a foundation of mineral plant nutrient, these consequences are attributed to the genotypic changes among the three sweet pepper hybrids. Plant biomass has been revealed to comparewith an rise of photo-assimilates, which regulate the amount of dry weight supply to basin organs (Dada and Ogunsesu, 2016)

Therising in total yield of 'Barbero', 'Ferrari', and 'Imperio' is credited to the rise in number of fruit per plant and the increased ratio of the superior fruit results. Comparableresults were also stated in 'Hybrid Ranco-365' chili pepper (Fathima and Denesh, 2013).

It is likewiseimagined that plant development hormones may be adsorbed onto humicsections and thus effect plant growth and development in a collective hormonal/humicconsequence (Atiyehet al., 2002). The usefulproperties of potassium humate on plant growth may be stated to its temporary as source of vegetalgrowinghormones(Abd El-Aalet al., 2005).

\section{MATERIALS AND METHODS}

The investigates were approved in the summer seasons of 2019 in research station Malta Duhok government, Kurdistan region / Iraq, toward studying the consequence of foliar spraying with Humiron on growing and produce of two sweet pepper hybrids California winder and Gulpinarpepper seeds (Capsicmannuun L.) were sown in trays thatcontained peat moss. Typical farming practices for Pepper nurserieswere approved out. Seedlings were transplanted in open field on the 10th of April.Two factors inrandomizecompleteblock Design (RCBD) was used by 3 replications, the first factors was two pepper hybrids (California wider(A) and Gulpiner (B)) the second factors was Humironat four levels $(0,10,20$ and 30 ml. $\mathrm{L}^{-1}$ ).and so the experiment contain of 8 treatments $(2 * 4)$.

The first foliar spray was after two weeks from planting, second and third foliar spraying in interval of 15 days from other.Five plant was selected to taken the data. Data were analysed by using SAS program AL-Rawi, Kh.M. and A.A.M. KhalafAlah (2000)

\section{RESULTS AND DISCUSSION \\ Plant height ( cm)}

Table (1) displaysthe significant difference between cultivars on plant height . Hybrid Gulpiner $85.17 \mathrm{~cm}$ compared with California winder $70.58 \mathrm{~cm}$ increasing by $17.13 \%$. Regarding the effect of Humiron acid no significant effect a supra plant height only little rising at level of $10 \mathrm{ml} . \mathrm{L}-179.83 \mathrm{~cm}$ compared with control $75.83 \mathrm{~cm}$. The interaction between Humic acid and cultivars, remarked significant difference $89.67 \mathrm{~cm}$ in cultivar gulpiner in level $10 \mathrm{ml} . \mathrm{L}^{-1}$ compared in a seam level in California wonder $70 \mathrm{~cm}$. These consequencesstay credited to the genotypic variances between the two sweet pepper hybrids. Plant biomass has stood shown to correlate with arise of photoassimilates, which decide the extent of dry weight supply to sink organs (Dada and Ogunsesu, 2016). Fathima andDenesh(2013)whostatedthatHumicacidrate was significant affected plant height of chilli. Yildirim(2007) has likewise findings in tomato crop.

\begin{tabular}{lrrrrr}
\hline \multirow{2}{*}{ Cultivars } & \multicolumn{5}{c}{ Humiron } \\
\cline { 2 - 7 } & Oml. $\mathrm{L}^{-1}$ & $10 \mathrm{ml} . \mathrm{L}^{-1}$ & $20 \mathrm{ml}^{-\mathrm{L}^{-1}}$ & $30 \mathrm{ml} . \mathrm{L}^{-1}$ & Effect of cultivars \\
\hline California wonder & $77.33 \mathrm{ab}$ & $70.00 \mathrm{~b}$ & $70.00 \mathrm{~b}$ & $65.00 \mathrm{~b}$ & $70.58 \mathrm{~b}$ \\
\hline Gulpiner & $74.33 \mathrm{ab}$ & $89.67 \mathrm{a}$ & $88.67 \mathrm{a}$ & $88.00 \mathrm{a}$ & $85.17 \mathrm{a}$ \\
\hline Effect of Humiron & $75.83 \mathrm{a}$ & $79.83 \mathrm{a}$ & $79.33 \mathrm{a}$ & $76.50 \mathrm{a}$ & \\
\hline
\end{tabular}

Table (1):-Effect of foliar spraying with different concentration of Humiron on plant height $(\mathrm{cm})$ of two sweet peppers Hybrid

Means within a column, row and their interactions followed with the same letters are not significantly different from each other according to Duncan's multiple range test at 5\% level. 


\section{Branches Number.plant ${ }^{-1}$}

The result show that in table (2) no difference between cultivars concerning the number of branches, only little increasing in cultivar California wonder (4.82)branches compared by Gulpiner (4.49) branches. Regarding the effect of Humiron, the result shows number of branches significantly affected by level of Humiron (30ml. L $\left.{ }^{-1}\right) 5.68$ branches, high dose offered baste result.Humic acid ratelikewisepretentious number of branches plant $^{-1}$ significantly. Humic acid is actualvital for root and shoot growth of the plant. It rises the approval of nutrients in vegetables plant (Cimrin and Yilmaz, 2005). Researchdisplayed that the foliar request of humic acid risevegetativegrowingoftheplant.Brownelletal.(1 987) described that foliar presentation of humic acid significantly rising number of branches plant $^{-1}$ in tomato. Concerning the intraction between cultivars and rate of humiron the result showed 6.15 branches in cultivar California winder at level of $30 \mathrm{ml} . \mathrm{L}^{-1}$ compared to control in a same cultivar (4.06) branches.

Table ( 2):-Effect of foliar spraying with different concentration of Humiron on number of branches.plant ${ }^{-1}$ of two sweet peppers hybrid

\begin{tabular}{lrrrrr}
\hline \multicolumn{1}{c}{ Cultivars } & \multicolumn{5}{c}{ Humiron } \\
\cline { 2 - 7 } & $0 \mathrm{ml} . \mathrm{L}^{-1}$ & $10 \mathrm{ml}^{-\mathrm{L}^{-1}}$ & $20 \mathrm{ml}^{\mathrm{L}} \mathrm{L}^{-1}$ & $30 \mathrm{ml}^{-\mathrm{L}^{-1}}$ & Effect of cultivars \\
\hline California wonder & $4.06 \mathrm{c}$ & $4.51 \mathrm{bc}$ & $4.56 \mathrm{bc}$ & $6.15 \mathrm{a}$ & $4.82 \mathrm{a}$ \\
\hline Gulpiner & $4.29 \mathrm{c}$ & $4.26 \mathrm{c}$ & $4.19 \mathrm{c}$ & $5.21 \mathrm{~b}$ & $4.49 \mathrm{a}$ \\
\hline Effect of Humiron & $4.18 \mathrm{~b}$ & $4.38 \mathrm{~b}$ & $4.38 \mathrm{~b}$ & $5.68 \mathrm{a}$ & \\
\hline
\end{tabular}

Means within a column, row and their interactions followed with the same letters are not significantly different from each other according to Duncan's multiple range test at 5\% level.

Fernández-Escobar et al. 1999 found that application of $\mathrm{HA}$ and $\mathrm{Ca}$ stimulated.High rate of Humironsimilarlypretentious number of branches .plant ${ }^{-1}$ significantly. Humic acid is a samevital for root and shoot growth of the plant. It increases the uptake of nutrients in vegetables crop (Cimrin and Yilmaz, 2005). The consequences are alike with the results of Dod et al.(1989)whoinformedthathumicacidcansignifica ntly affect number of branches.plant ${ }^{-1}$. The comparable results were toodescribed by Fathima and Denesh(2013).

\section{Chlorophyll content}

Table 3 indicate that the leaves content of total chlorophyll content,no significant variance between hybrids only California wonder with 60.05 was over Gulpiner 56.22 rise by $6.37 \%$. The effect Humironshow that the chlorophyll contentedreallyreplied to the diverse foliar applicationbyHumiron,remarked that no significant among spraying with Humiron, 59.85 at rate of $30 \mathrm{ml}^{-L^{-1}}$ compared by un treated 55.05 Fernández-Escobar et al. found that application of HA and Caencouraged chlorophyll contentedConcerning the interaction between hybrids and spraying with Humiron, no significant difference, California wonder 63.00 was a supra Gulpiner 52.57 umtreated.

Table ( 3):-Effect of foliar spraying with different concentration of Humiron on chlorophyll of two sweet peppers hybrid.

\begin{tabular}{|c|c|c|c|c|c|}
\hline \multirow[t]{2}{*}{ Cultivars } & \multicolumn{4}{|c|}{ Humiron } & \\
\hline & $0 \mathrm{ml} \cdot \mathrm{L}^{-1}$ & $10 \mathrm{ml} \cdot \mathrm{L}^{-1}$ & $20 \mathrm{ml}^{2} \mathrm{~L}^{-1}$ & $30 \mathrm{ml}^{-\mathrm{L}^{-1}}$ & Effect of cultivars \\
\hline California wonder & $57.53 \mathrm{a}$ & $56.50 \mathrm{a}$ & $63.17 \mathrm{a}$ & $63.00 \mathrm{a}$ & $60.05 \mathrm{a}$ \\
\hline Gulpiner & $52.57 \mathrm{a}$ & $59.90 \mathrm{a}$ & $55.70 \mathrm{a}$ & $56.70 \mathrm{a}$ & $56.22 \mathrm{a}$ \\
\hline Effect of Humiron & $55.05 a$ & $58.20 \mathrm{a}$ & $59.43 \mathrm{a}$ & $59.85 a$ & \\
\hline
\end{tabular}

Means within a column, row and their interactions followed with the same letters are not significantly different from each other according to Duncan's multiple range test at $5 \%$ level.

\section{Fresh weight $(\mathbf{k g})$}

Fresh weight is an important structure of plant, which is the centralbasisofnutritiontoplantasthephotosynthesi $\mathrm{s}$ ensuedinit.Together foliar or soil presentation of humic acid improved fresh mass and fullharvest in (Karakurtet al., 2009) The result in table ( 4 ) showed that no significant difference between cultivars legate fresh weight. Regarding the effect of Humiron, result demonstrations 
significant variance among rate of Humiron applicant, at level of $30 \mathrm{ml} . \mathrm{L}^{-1} \quad 0.74 \mathrm{~kg}$ compared by other level of plant spraying high dose of Humiron due to increasing vegetative biomasses.Concerning the collaboration between Hybrids and level of Humiron, commented significant difference. At rate $30 \mathrm{ml} . \mathrm{L}^{-1} 0.81 \mathrm{~kg}$ at
California wonder comparative by control 0.50 ay Gulpiner rise by $38.27 \%$.

\begin{tabular}{|c|c|c|c|c|c|}
\hline \multirow[t]{2}{*}{ Cultivars } & \multicolumn{4}{|c|}{ Humiron } & \\
\hline & $0 \mathrm{ml} . \mathrm{L}^{-1}$ & $10 \mathrm{ml}^{-\mathrm{L}^{-1}}$ & $20 \mathrm{ml}^{\prime} \mathrm{L}^{-1}$ & $30 \mathrm{ml}^{-\mathrm{L}^{-1}}$ & Effect of cultivars \\
\hline California wonder & $0.54 \mathrm{bc}$ & $0.41 \mathrm{c}$ & $0.68 \mathrm{ab}$ & $0.81 \mathrm{a}$ & $0.61 \mathrm{a}$ \\
\hline Gulpiner & $0.50 \mathrm{bc}$ & $0.53 \mathrm{bc}$ & $0.67 \mathrm{a}-\mathrm{c}$ & $0.68 \mathrm{ab}$ & $0.59 a$ \\
\hline Effect of Humiron & $0.52 \mathrm{bc}$ & $0.47 \mathrm{c}$ & $0.67 a b$ & $0.74 \mathrm{a}$ & \\
\hline
\end{tabular}

Table ( 4):-Effect of foliar spraying with different concentration of Humiron on fresh weight (kg) of two sweet peppers hybrid

Means within a column, row and their interactions followed with the same letters are not significantly different from each other according to Duncan's multiple range test at 5\% level.

\section{Dry weight ( g)}

Data present in table (5) shows that the dry weight in peppers hybrid, about the effect of hybrids nosignificant variance between hybrids. Regarding the effect of Humieon, nosignificant difference among Humiron, only high amount of Humiron provided best result. Cocerning the interaction between Hybrids and foliar application of Humiron no significant difference between parameter studies.

Table ( 5):-Effect of foliar spraying with different concentration of Humiron on dry weight (g) of two sweet peppers hybrid

\begin{tabular}{|c|c|c|c|c|c|}
\hline \multirow[t]{2}{*}{ Cultivars } & \multicolumn{4}{|c|}{$\begin{array}{c}\text { Humiron } \\
\end{array}$} & \multirow[b]{2}{*}{ Effect of cultivars } \\
\hline & $0 \mathrm{ml} \cdot \mathrm{L}^{-1}$ & $10 \mathrm{ml}^{\prime} \mathrm{L}^{-1}$ & $20 \mathrm{ml} \mathrm{L}^{-1}$ & $30 \mathrm{ml}^{-\mathrm{L}^{-1}}$ & \\
\hline California wonder & $81.17 \mathrm{a}$ & $80.83 a$ & $93.83 \mathrm{a}$ & $83.37 \mathrm{a}$ & $84.80 \mathrm{a}$ \\
\hline Gulpiner & $85.03 \mathrm{a}$ & $79.30 \mathrm{a}$ & $85.80 \mathrm{a}$ & $84.50 \mathrm{a}$ & $83.66 \mathrm{a}$ \\
\hline Effect of Humiron & $83.10 \mathrm{a}$ & $80.07 \mathrm{a}$ & $89.82 \mathrm{a}$ & $83.93 \mathrm{a}$ & \\
\hline
\end{tabular}

Means within a column, row and their interactions followed with the same letters are not significantly different from each other according to Duncan's multiple range test at 5\% level.

\section{Vitamin $\mathbf{C}\left(\mathbf{m l} .100 \mathrm{~g}^{-1}\right)$}

Table 6 shows that the content of vitamin $\mathrm{C}$ in two hybrids of pepper, no variance between hybrids regarding vitamin $\mathrm{c}$ content .About the consequence of Humiron on contented of vitamin Cobserved significant difference among level of Humiron, 24,55 compared by un treated $18.81 \mathrm{ml}^{100 \mathrm{~g}^{-1}}$.

$\mathrm{g}$ About the interaction between hybrids and Humiron, the high level in both hybrids are significant compared with untreated plant.

Table ( 6): Effect of foliar spraying with different concentration of Humiron on vitamin $\mathrm{C}\left(\mathrm{ml} .100 \mathrm{~g}^{-1}\right)$ of two sweet peppers hybrid

\begin{tabular}{lrrrrr}
\hline \multicolumn{1}{c}{ Cultivars } & \multicolumn{4}{c}{ Humiron } \\
\hline & Oml. $\mathrm{L}^{-1}$ & $10 \mathrm{ml}^{-1}$ & $20 \mathrm{ml}^{-1}$ & $30 \mathrm{ml}^{-1} \mathrm{~L}^{-1}$ & $\begin{array}{c}\text { Effect of } \\
\text { cultivars }\end{array}$ \\
\hline California wonder & $18.81 \mathrm{~b}$ & $20.69 \mathrm{ab}$ & $21.46 \mathrm{ab}$ & $24.55 \mathrm{a}$ & $21.38 \mathrm{a}$ \\
\hline Gulpiner & $18.81 \mathrm{~b}$ & $20.69 \mathrm{ab}$ & $21.46 \mathrm{ab}$ & $24.55 \mathrm{a}$ & $21.38 \mathrm{a}$ \\
\hline $\begin{array}{l}\text { DaEffect of } \\
\text { Humiron }\end{array}$ & $18.81 \mathrm{~b}$ & $20.69 \mathrm{~b}$ & $21.46 \mathrm{ab}$ & $24.55 \mathrm{a}$ & \\
\hline
\end{tabular}

Means within a column, row and their interactions followed with the same letters are not significantly different from each other according to Duncan's multiple range test at 5\% level. 


\section{Fruit number/plant}

Data presented in table ( 7 ) clearly shown thatnumber of fruit/plant, hybrid California wonder was significant difference compared with hybrid Gulpiner 19.46 fruit compared with Gulpiner 18.68 fruit raised by $4 \%$. Regarding the effect of foliar spray by Humiron, significant result obtained at level of $30 \mathrm{ml} . \mathrm{L}^{-1} 20.68$ compared with control 17.80 . variation was observed between cultivars and fruit numbers plant $^{-1}$ and this differencemay be due to genetic motivesPadem and Ocal (1999) who decided that diverse concentration of humic acid application results a significant variation in number of fruits plant $^{-1}$.. The difference in growing character below alike circumstances might be due to genetic influences (Kishan and Suryanarayan, 2004). Obidiebube et al.(2012)described that there is a significant difference between cultivars in number of fruits plant $^{-1}$. With the application of humic acid levels, number of fruits plant ${ }^{-1}$ was significantly better. It has remaineddescribed by Karakurt et al. (2009). The interaction between cultivars and level of Humiron applicator at rate of 30ml.L-1 were significant at hybrid of California wonder 21.63 fruits, compared with no sprayed in a seam hybrid 17.49 fruit.

Table ( 7):Effect of foliar spraying with different concentration of Humiron on fruit numbers of two sweet peppers hybrid

\begin{tabular}{|c|c|c|c|c|c|}
\hline \multirow{2}{*}{ Cultivars } & \multicolumn{4}{|c|}{ Humiron } & \\
\hline & Oml.LL-1 & $10 \mathrm{ml}^{-\mathrm{L}^{-1}}$ & $20 \mathrm{ml}^{. \mathrm{L}^{-1}}$ & $30 \mathrm{ml}^{. \mathrm{L}^{-1}}$ & Effect of cultivars \\
\hline California wonder & $17.49 \mathrm{e}$ & $18.52 \mathrm{c}-\mathrm{e}$ & $20.22 \mathrm{~b}$ & $21.63 \mathrm{a}$ & $19.46 \mathrm{a}$ \\
\hline Gulpiner & $18.11 \mathrm{de}$ & $17.85 \mathrm{de}$ & $19.06 \mathrm{~b}-\mathrm{d}$ & $19.69 \mathrm{bc}$ & $18.68 \mathrm{~b}$ \\
\hline Effect of Humiron & $17.80 \mathrm{c}$ & $18.19 \mathrm{c}$ & $19.64 \mathrm{~b}$ & $20.66 \mathrm{a}$ & \\
\hline
\end{tabular}

Means within a column, row and their interactions followed with the same letters are not significantly different from each other according to Duncan's multiple range test at 5\% level.

\section{Fruit weight (g)}

Data presented in table (8) show effect of Humiron a supra fruits weight of two peppers cultivar, California wonder was significant modification to Gulpiner0.73g respective $0.67 \mathrm{~g}$.Concerning the effect of Humiron a supra fruits weight the above table shows spraying with $30 \mathrm{ml} . \mathrm{L}^{-1}$ provided significant difference
$0.82 \mathrm{~g}$ comparative with un treated $0.59 \mathrm{~g}$. Regarding the interaction between hybrids and Humiron, the result show that hybrid California wonder $0.88 \mathrm{~g}$ was significant difference to un treated Gulpiner $0.55 \mathrm{~g}$ rise by $37.5 \%$. The variant of fruits weight due to genetic reason.Fitrianietal.(2013)

Table ( 8):-Effect of foliar spraying with different concentration of Humiron on fruit weight ( $\mathrm{g}$ ) of two sweet peppers hybrid

\begin{tabular}{lccccc}
\hline \multicolumn{1}{c}{ Cultivars } & \multicolumn{5}{c}{ Humiron } \\
\hline & $0 \mathrm{ml} . \mathrm{L}^{-1}$ & $10 \mathrm{ml}^{-\mathrm{L}^{-1}}$ & $20 \mathrm{ml}^{-\mathrm{L}^{-1}}$ & $30 \mathrm{ml}^{-\mathrm{L}^{-1}}$ & Effect of cultivars \\
\hline California wonder & $0.64 \mathrm{~d}-\mathrm{f}$ & $0.61 \mathrm{ef}$ & $0.77 \mathrm{~b}$ & $0.88 \mathrm{a}$ & $0.73 \mathrm{a}$ \\
\hline Gulpiner & $0.55 \mathrm{f}$ & $0.66 \mathrm{c}-\mathrm{e}$ & $0.73 \mathrm{bc}$ & $0.76 \mathrm{bc}$ & $0.67 \mathrm{~b}$ \\
\hline Effect of Humiron & $0.59 \mathrm{c}$ & $0.64 \mathrm{c}$ & $0.75 \mathrm{~b}$ & $0.82 \mathrm{a}$ & \\
\hline
\end{tabular}

Means within a column, row and their interactions followed with the same letters are not significantly different from each other according to Duncan's multiple range test at 5\% level.

\section{Plant Yield (kg.plant $\left.{ }^{-1}\right)$}

Data presented in table 9 shows the yield/plant, there are significant difference between the hybrid, California wonder gave $1.478 \mathrm{~kg}$.plant ${ }^{-1}$ comparative by gulpiner 1.347 kg.plant ${ }^{-1}$.The difference due to high fruits/plant and fruits weight in hybrid California wonder. The effect of Humiron on kg.plant ${ }^{-1}$ remarked significant variance among level of Humiron, At level of $30 \mathrm{~m} \cdot \mathrm{L}^{-1} 1.863 \mathrm{~kg} \cdot \mathrm{plant}^{-1}$ comparative with untraded plant $1.170 \mathrm{~kg}$.plant ${ }^{-1}$ The variation yield plant $^{-1}$ in different chilli varieties wasduetogeneticreasonsandbigvarietaldifference s (Rajput et al., 1999). The interaction between Hybrids and Humiron observer significant difference between Hybrids and sparing by Humiron Hybrid California wonder at rate of $30 \mathrm{ml} . \mathrm{L}^{-1} 1.903 \mathrm{~kg} \cdot \mathrm{plant}^{-1}$ comparative with un sprayed Gulpiner $1.013 \mathrm{~kg}$.plant ${ }^{-1}$ 
Table ( 9):-Effect of foliar spraying with different concentration of Humiron on yield kg.plant ${ }^{-1}$ of two sweet peppers hybrid

\begin{tabular}{lrrrrr}
\hline \multicolumn{1}{c}{ Cultivars } & \multicolumn{7}{c}{ Humiron } \\
\hline & \multicolumn{1}{c}{ Oml. $\mathrm{L}^{-1}$} & $10 \mathrm{ml}^{-1}$ & $20 \mathrm{ml}^{-1} \mathrm{~L}^{-1}$ & $30 \mathrm{ml} . \mathrm{L}^{-1}$ & Effect of cultivars \\
\hline California wonder & $1.327 \mathrm{bc}$ & $1.120 \mathrm{~cd}$ & $1.560 \mathrm{~b}$ & $1.903 \mathrm{a}$ & $1.478 \mathrm{a}$ \\
\hline Gulpiner & $1.013 \mathrm{~d}$ & $1.163 \mathrm{~cd}$ & $1.387 \mathrm{bc}$ & $1.823 \mathrm{a}$ & $1.347 \mathrm{~b}$ \\
\hline Effect of Humiron & $1.170 \mathrm{c}$ & $1.142 \mathrm{c}$ & $1.473 \mathrm{~b}$ & $1.863 \mathrm{a}$ & \\
\hline
\end{tabular}

Means within a column, row and their interactions followed with the same letters are not significantly different from each other according to Duncan's multiple range test at $5 \%$ level.

\section{Yield $\left(\mathrm{kg} / \mathrm{m}^{2}\right)$.}

Regarding the yield $\mathrm{kg} / \mathrm{m}^{2}$, in data present in table ( 10$)$ shows the significant variance between hybrids, hybrid California wonder was superior over Gulpiner $4.19 \mathrm{~km} / \mathrm{m}^{2}$ respective $3.57 \mathrm{~kg} / \mathrm{m}^{2}$ rising by $14.80 \%$. Concerning the effect of Humiron on yield $\mathrm{kg} / \mathrm{m} 2$, spraying with
$30 \mathrm{~m} . \mathrm{L}^{-1}$ gave $4.79 \mathrm{~kg} / \mathrm{m}^{2}$ compared with control $3.32 . \mathrm{kg} / \mathrm{m}^{2}$.About the interaction between hybrids and Humiron, hybrid California wonder at level of $30 \mathrm{ml}^{-1} \mathrm{~L}^{-1} 5.40 \mathrm{~kg} / \mathrm{m}^{2}$ comparative by control no treated $2.87 \mathrm{~kg} / \mathrm{m}^{2}$ in Gulpiner. Increasing the yield in California wonder due to number of fruit/plant and fruits weigh.

Table ( 10):-Effect of foliar spraying with different concentration of Humiron on yield $\mathrm{kg} . \mathrm{m}^{2}$ of two sweet peppers hybrid

\begin{tabular}{|c|c|c|c|c|c|}
\hline \multirow[t]{2}{*}{ Cultivars } & \multicolumn{4}{|c|}{ Humiron } & \\
\hline & $0 \mathrm{ml} \cdot \mathrm{L}^{-1}$ & $10 \mathrm{ml} \cdot \mathrm{L}^{-1}$ & $20 \mathrm{ml} \cdot \mathrm{L}^{-1}$ & $30 \mathrm{ml}^{2} \mathrm{~L}^{-1}$ & Effect of cultivars \\
\hline California wonder & $3.76 \mathrm{bc}$ & $3.18 \mathrm{~cd}$ & $4.42 \mathrm{~b}$ & $5.40 \mathrm{a}$ & $4.19 \mathrm{a}$ \\
\hline Gulpiner & $2.87 \mathrm{~d}$ & $3.30 \mathrm{~cd}$ & $3.93 \mathrm{bc}$ & $4.18 b$ & $3.57 \mathrm{~b}$ \\
\hline Effect of Humiron & $3.32 \mathrm{c}$ & $3.24 \mathrm{c}$ & $4.18 \mathrm{~b}$ & $4.79 a$ & \\
\hline
\end{tabular}

Means within a column, row and their interactions followed with the same letters are not significantly different from each other according to Duncan's multiple range test at $5 \%$ level.

\section{Yield (ton.ha-1)}

Table (11) illustrated the effect of hybrids on yield t.ha ${ }^{-1}$, remarked that hybrid California wonder provided 41.91 t.ha $^{-1}$ comparative with hybrid Gulpiner 35.82 t.ha $^{-1}$. Concerning the effect of Humiron on yield,foliar with humic acid leading to a significant growth in the amount per plant and total yield (Elnemiret al ;2012).highdoze gave better result 48.10 t.ha $^{-}$ ${ }^{1}$ comparative by untreated 33. 18 t.ha $^{-1}$ rise by $31.01 \%$.
Regarding the interaction between hybrids and spraying with Humiron the result shows the significant change, hybrid California wonder provided 54.00 t.ha $^{-1}$ comparative with un treated at Gulpiner 28.73 t.ha ${ }^{-1}$. The result due to better environmental suitable condition, or genetic variation even high number of fruits/plant and fruits weight (Zhang and Erwin, 2004),in hybrid California wonder. The fullproduce was better by foliar presentation of Humiron.

Table ( 11):-Effect of foliar spraying with different concentration of Humiron on yield ton.ha ${ }^{-1}$ of two sweet peppers hybrid

\begin{tabular}{|c|c|c|c|c|c|}
\hline \multirow[t]{2}{*}{ Cultivars } & \multicolumn{4}{|c|}{ Humiron } & \multirow[b]{2}{*}{ Effect of cultivars } \\
\hline & $0 \mathrm{ml} \cdot \mathrm{L}^{-1}$ & $10 \mathrm{ml} . \mathrm{L}^{-1}$ & $20 \mathrm{mLL}^{-1}$ & $30 \mathrm{ml}^{-\mathrm{L}^{-1}}$ & \\
\hline California wonder & $37.63 \mathrm{bc}$ & $31.77 \mathrm{~cd}$ & $44.23 \mathrm{~b}$ & $54.00 \mathrm{a}$ & $41.91 \mathrm{a}$ \\
\hline Gulpiner & $28.73 \mathrm{~d}$ & $33.00 \mathrm{~cd}$ & $39.33 \mathrm{bc}$ & $42.20 \mathrm{~b}$ & $35.82 \mathrm{~b}$ \\
\hline Effect of Humiron & $33.18 \mathrm{c}$ & $32.38 \mathrm{c}$ & $41.78 \mathrm{~b}$ & $48.10 \mathrm{a}$ & \\
\hline
\end{tabular}

Means within a column, row and their interactions followed with the same letters are not significantly different from each other according to Duncan's multiple range test at $5 \%$ level. 


\section{CONCLUSIONS AND RECOMMENDATIONS}

Afterthe total results of the research, it is decided that hybrid California wonder do better under the climatic conditions of dohuk. Also, foliar application of Homiron at the rate of $30 \mathrm{ml}^{-1}$ give greatest results. The application of $30 \mathrm{ml}-1$ Humiron to high California wonder Hybrid for the commercial production should be recommended for the climatic conditions of Dohuk.

\section{REFERENCES:}

Abd EL-Aal, F.; M.R. Shafeek; A.A. Ahmed and A.M. Shaheen. (2005). Response of growth and yield of onion plants to potassium fertilizer and humic acid. J. Agric. Sci. Mansoura Univ., 30(1):441-452.

AL-Rawi, Kh.M. and A.A.M. KhalafAlah (2000). Design and analysis of Agricultural experiments. Musol Univ. Ministry of Higher Education and Scientific Research. Iraq. (In Arabic).

Atiyeh, R.M., Edwards, C.A., Metzger, J.D., Lee, S., \&Arancon,

Atiyeh, R.M, ;C.A,Edwards; J.D,Metzger; S.Lee, and N. QArancon (2002). The influence of humic acid derived from earthworm- processed organic wasteson plant growth .Bioresurce. Technology, 84, 7- 14.

Brownell,J.R.;G.Nordstrom;J.MarihartandG. Jorgensen. (1987). Crop responses from two new leonardite extracts. Sci. Total Environ. 62: 491-499.https://doi.org/10.1016/0048-

Cheng, Y .; Y Zheng; C. Tai; J. Yen; Y Chen, and F. Jan. ( 2014 ). Identification, characterization and detection of a new tospoviru on sweet pepper. Annals of Applied Biology, 164 (1): 107-115.

Cimrin, K.M. and I. Yilmaz. (2005). Humic acid applications to lettuce do not improve yield but do improve phosphorus availability. Acta Agric.Scand.,Sect.B,SoilPlantSci.55:5863.https://doi.org/10.1080/0906471051000855 9

Dada, O.A. \& Ogunsesu, Y.O. (2016). Growth analysis and fruit yield of Capsicum chinense, Jacquin as influenced by compost applied as foliar spray and soil augmentation in Ibadan, southwestern Nigeria J. Agr. Sustainability 983103

Dod, V.N.: P.B. Kale and R.S. Ranotokar. (1989). Effect of foliar application of auxins andmicronutrients on growth and yield of chilli.PunjabraoKrishiVidyapeeth Res. J., 13: 29-33.
El-Nemr, M.A.,M EL-Desuki, A.M.EL-Bassiony and Z.F. Fawzea (2012) .Respose of Growth and Yield of Cucumber plants (Cucumissativus L.) to Different Foliar Applications of Humic acid and Bio stimulators . Australian Journal of Basic and Applied Sciences, 6(3), 2012, 630637.

Fathima, P.S. \& , G.R.Denesh( 2013). Influence of humic acid spray on growth and yield of chili (Capsicum annuum L.) Intl. J. Agr. Sci. 9542546

Fernández-Escobar, R..; M. Benlloch; D. Barranco; A. Dueñas\& J.A. GutérrezGañán, (1999). Response of olive trees to foliar application of humic substances extracted from leonardite. ScientiaHorticulturae, 66(3-4): 191-200.

Kishan, K., S. Swaroop and M.A. Surayanarayana. (2004). Response of Chilli Genotypes for Green Fruit Yield and Bacterial Wilt in Bay Islands. Karnataka J. Agric. Sci., 17 (4): 88689

Kaiser, C., and M. Ernst (2014). Hot Peppers and Specialty Sweet Peppers. University of Kentucky Cooperative Extension. Center for Crop Diversification Crop Profile (CCD-CP101)

Karakurt, Y.; H. Unlu and H. Padem (2009). The influence of foliar and soil fertilization of humic acid on yield and quality of pepper. Acta Agriculture Scandinavica Section B Plant Soil Science 59 (3): 233-237

Kuhar,T. P; Aracibia, S. L, Redeut, and M.S. Reiter. (2017 ) Southeastern U S Vegetable crop Hand book. P.305.

Mackowiak, C.L.; P.R. Grossl and B.G Bugbee (2001). Beneficial effect of humic acid on micronutrients availability to wheat. S,,oil Sci. Soc. Am. J. 2001, 65: 1744- 1751.

Mackowiaket, G.;P.E. Nelson; R.A. Hilland; N. Spencer (2001). Pepper taxonomy and the botanical description of the species. ActaAgron. Hungarica. 54: 151-166. https://doi.

Obidiebube, E.A.;P.G. Eruotor;S.O. Akparobi;S.O. Emosaariue;U.A. Achebe and P.E. Kator.

(2012). Response of four cultivars of pepper (Capsicum frutescensL.) to different levels ofN.P.K. fertilizer in rainforest agro ecological zone. Int. J. Agric. Sci., 2(12): 1143-1150.

Padem, H.;, A. Ocal and R. Alan (1999). Effect of Humic Acid Added Foliar Fertilizer on Quality and Nutrient Content of Eggplant and Pepper Seedlings. ActaHorticulturae, 491, 169-

177.https://doi.org/10.17660/actahortic.1999.4 91.35

Rajput,J.C.;S.B.PalweandP.B.Patil,(1999).Varietal evaluation of red chilliesfor, yield and quality in Konkan region of Maharastra. Indian Cocoa,Arecanut Spices J., 14:107-108. 
Zhang, X and E.H. Ervin. (2004). Cytokinincontaining seaweed and humic acid extracts associated with creeping bentgrass leaf cytokinins and drought resistance. Crop. Sci. 44: $1737-1745$.

Zandonadi, D. B.; L.P. Cancllas, and, A. R Facanha (2007). INdolacetic and Humic acid indoce lateral root development through a concerted plasma lemma and tonoplast $\mathrm{H}+$ pomp activation. Planta, 225 1583-1595.

Yildirim, E. (2007). Foliar and soil fertilization of humic acid offered productivity and quality of tomato. Acta Agriculture scandnavica section B- soil. Plant sci. 57: 182 - 186 https://Doi. Org/10. 1080/09064710600813

Indolacetic and humic acids induce lateral root development

Indolacetic and humic acids induce lateral root development

Indolacetic and humic acids induce lateral root development

Indolacetic and humic acids induce lateral root $\mathrm{d}$

يوخته

ئه ثه قهولينه يا هاتيه ئهنجام دان لنافا بيستاني قهكولينيّت جاندنى يا قهكرى ل مالتا -دهوك- ههريّما

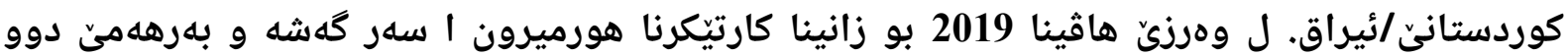

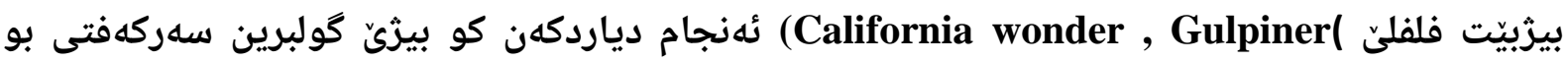
دبلنديا رووهكى و زمارا تاكا و كليفورنيا ئو ووندهر سهركهفتى بو بشيّوهى يشووهرى دزمارا بهرههمى و

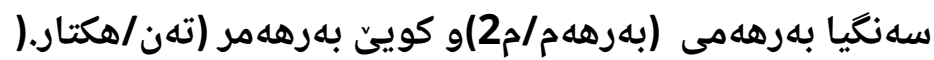

هوميرونى بلنديا رووهكى و زمارا تاكا زيّدهر بريّزا بلند و فيتامين c و قهبارا بهرههمى(بهرههم ارووهك) ائو كويسّ بهرههمى (تهن/هكتار). 